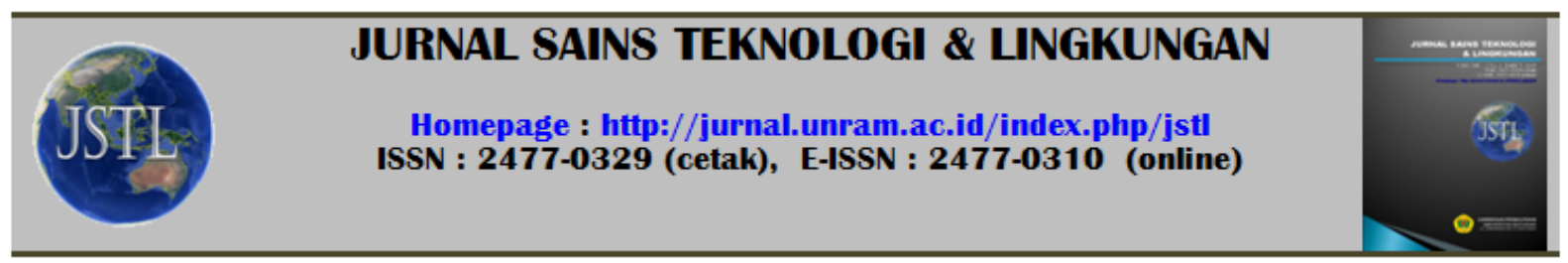

\title{
ANALISIS PENDUKUNG PENGAMBILAN KEPUTUSAN PRIORITAS PENATAAN PEMAKAMAN DI KOTA MATARAM BERBASIS SISTEM INFORMASI GEOGRAFIS
}

${ }^{1)}$ Lalu Agus Supriyadi, ${ }^{1)}$ Didi Supriyadi Agustawijaya, ${ }^{1)}$ I Ketut Budastra $\left.{ }^{1}\right)$ Magister Teknik Sipil Pascasarjana Universitas Mataram

\begin{tabular}{l} 
Kata kunci : \\
\hline Pengambilan \\
Keputusan, \\
RTH, GIS, \\
SMCE, AHP
\end{tabular}

Abstrak

Pertumbuhan ekonomi dan penduduk serta pembangunan yang pesat ditandai penambahan pusat-pusat aktivitas baru di kota Mataram. Hal ini dikhawatirkan berimplikasi pada keterbatasan areal pemakaman sebagai bagian dari RTH publik sesuai amanat Undangundang nomor 26 tahun 2007 tentang Tata Ruang. Permasalahan pemakaman yang dihadapi oleh Pemerintah Kota Mataram adalah belum terpetakan dan tertatanya areal permakaman yang sudah ada serta cara mendapatkan lahan pengembangan makam sampai tahun 2030 sesuai amanat RTRW Kota Mataram. Untuk mencapai tujuan perancangan pengambilan keputusan berbasis spasial perlu dilakukan inventarisasi, estimasi kebutuhan areal makam dan pengembangan makam serta penentuan prioritas penataan fisik makam. Penelitian ini menggunakan teknologi berbasis sistem informasi geografis dengan jumlah makam yang terinventarisasi di Kota Mataram sebanyak 100 makam. Total luasannya $494.890 \mathrm{~m} 2$ yang terdiri dari 83 makam muslim, 1 makam pahlawan dan 16 makam non muslim. Berdasarkan PERMENPU nomor 5/PRTM/2008, estimasi kebutuhan lahan pemakaman sampai tahun 2030 seluas 114,89 ha dengan kekurangan lahan makam muslim 33,53 ha dan non muslim 7,85 ha. Hasil analisis menunjukkan terdapat 18 lokasi area pengembangan makam di Kota Mataram seluas 61 ha $(610.625 \mathrm{~m} 2)$ dengan 16 lokasi untuk pengembangan makam muslim umum. Dari hasil Analitik Hirarki Proses lanjutan, makam yang paling diprioritaskan dalam penataan fisik adalah makam Bagirati di Kecamatan Cakranegara dengan bobot $32 \%$.

Key words :
Making,
RTH, GIS,
SMCE, AHP

Abstract

Economic development and population growth marked the addition of new activity centers in the city of Mataram. It is be apprehensive that the limited area of the cemetery as part of a public green space as mandated by Spatial Law No. 26 of 2007 will be implicated. The City of Mataram faces unmapped funeral problem and unwell-organized area cemeteries that already exist as well as how to obtain land for cemetery development until 2030 as mandated by the RTRW Mataram. To achieve the design goal based on spatial decision, it is necessary to inventory the estimated needs of the cemetery area and the prioritization of the basic arrangement. Based on geographic information system technology covering total area of 494,890 m2, this study explored 100 existing cemeteries in Mataram consists of 83 Muslim's Cemeteries, 16 Non-Muslim's Cemeteries and 1 Hero's Grave. Based on PERMENPU No. 5/PRTM/2008, the estimated needs burial ground until 2030 is 114.89 ha, with the shortage areas of 33.53 ha and 7.85 ha for Muslim and Non-Muslims cemeteries, respectively. The results indicated there are 18 locations for developing cemeteries area covering 61 ha $(610,625.10 \mathrm{~m} 2)$ in Mataram City where 16 of them for the development of a common Muslim cemeteries. From the results of Analytical Hierarchy Process, the most prioritized in the physical arrangement is Bagirati cemetery in Cakranegara District with $32 \%$ score. 


\section{PENDAHULUAN}

Tempat pemakaman di kota Mataram saat ini masih belum terkelola dengan maksimal dan belum terencana dan tertata dengan baik dari segi fisik maupun administrasinya. Hanya ada data primer 54 makam di Kota Mataram dengan lokasi tersebar dan belum terpetakan serta tertata secara spasial yang menimbulkan kesulitan untuk mendapatkan lokasi pengembangan makam. Kendala lain adalah pengaruh budaya dan ego sektoral terhadap pendatang yang akan dimakamkan serta belum jelasnya sistem retribusi pemakaman sehingga perlu penataan ulang tata ruang pemakaman dan manejemen pemakaman yang baik. Instrumen pengendali dengan teknologi Sistem Informasi Geografis (SIG) akan membantu dalam analisis dan mendukung pengambilan keputusan penentuan prioritas penataan makam di Kota Mataram agar tertata menjadi lebih baik.

Penelitian ini bertujuan untuk melakukan analisis dalam pengambilan keputusan prioritas penataan pemakaman di Kota Mataram berbasis sistem informasi geografis dengan melakukan inventarisir jumlah dan luas makam serta menghitung estimasi kebutuhan lahan pemakaman sampai dengan tahun 2030. Untuk itu dilakukan analisis Sistem Multi Kriteria Evaluasi (SMCE) dan GIS dengan kriteria Kebijakan, Ekonomi, Fisik dan Sosial Budaya untuk pendukung pengambilan keputusan pencarian lokasi pengembangan area pemakaman serta menentukan penataan fisik makam prioritas.

Penelitian sejenis dilakukan Dian (2004) dari ITC dengan menggunakan sistem pendukung keputusan berbasis spasial dalam kasus pemakaman di kota Guilin China. Metode yang digunakan adalah SMCE dengan program Illwiss. Penelitian yang sama juga dilakukan oleh Riyadi (2008) untuk pencarian lokasi baru pemakaman di perkotaan. Pemanfaatan SIG dengan perangkat lunak ArchGIS dan proses AHP digunakan dalam penelitian ini untuk mengidentifikasi kesesuaian lahan yang efisien dan terkendali terkait pemakaman yang ada di kota Mataram. Sistem Informasi Geografi (SIG) adalah suatu sistem basis data dengan kemampuan khusus untuk menangani data yang bereferensi keruangan (spasial) bersamaan dengan seperangkat operasi kerja (Barus dan Wiradisastra, 2000).

Analisis Multi Kriteria (AMK) adalah perangkat pengambilan keputusan yang dikembangkan untuk masalah-masalah kompleks multikriteria yang mencakup aspek kualitatif dan atau kuantitatif dalam proses pengambilan keputusan. Tiga perangkat utama yang merupakan komponenkomponen penting dari kerangka analisis adalah Kriteria, Sub Kriteria (Indikator) dan Pengukur (CIFOR, 1999).

Untuk Penilaian Kriteria dan Indikator dilakukan Penetapan Peringkat dan Penetapan Nilai. Kombinasi antara evaluasi kriteria majemuk dengan
SIG berbasis spasial (spatial multiple criteria evaluation/SMCE) merupakan cara yang digunakan untuk menghasilkan kebijakan dalam pengambilan keputusan yang terkait dengan masalah informasi spasial pemakaman.

Penerapan AHP pada penelitian ini untuk mendapatkan bobot penilaian kriteria dan Indikator (sub kriteria). Penilaian ini berguna untuk penentuan analisis pencarian klas kesesuaian lahan makam dalam pencarian lokasi untuk pengembangan makam. Sehingga dapat ditentukan urutan prioritas penataan makam. Selanjutnya pola pikir penelitian ini dapat dilihat pada bagan-alir di Gambar 1

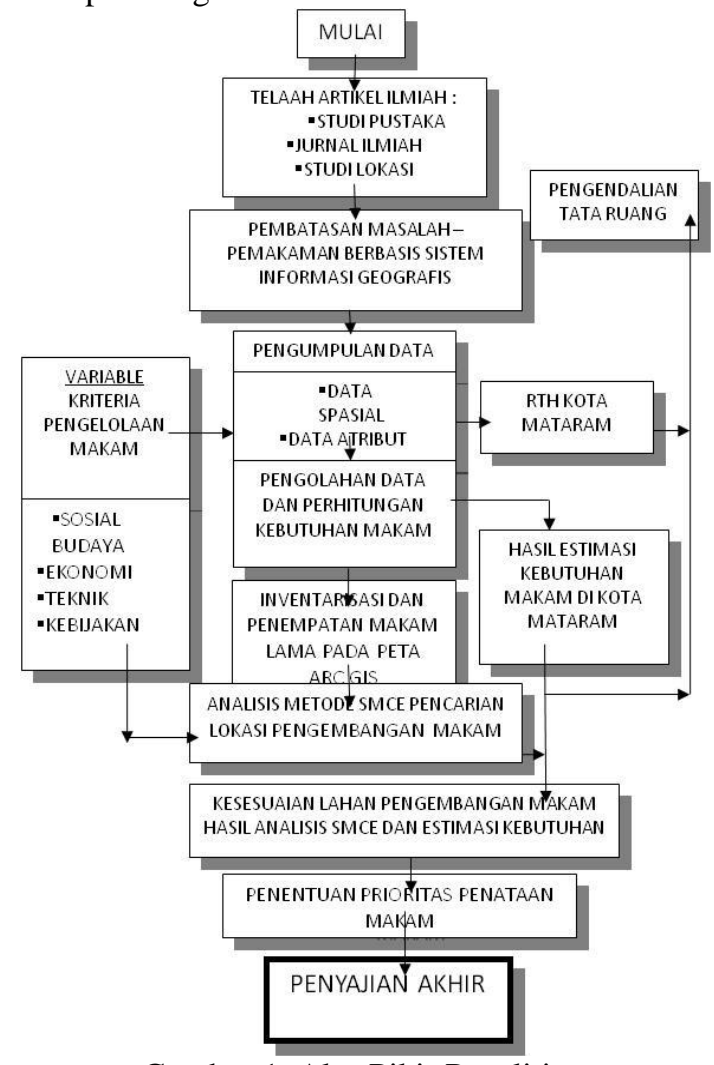

Gambar 1. Alur Pikir Penelitian

\section{METODOLOGI PENELITIAN}

Penelitian ini dilaksanakan pada pertengahan tahun 2014 dengan mengambil lokasi di Kota Mataram. Pendekatan yang dilakukan dalam penelitian ini adalah pendekatan kualitatif secara deskriptif, normatif dan spasial. Penelitian selanjutnya dipertajam dengan metode kuantitatif untuk mencapai tujuan yang diharapkan dengan metode SMCE dan AHP.

\section{Bahan Penelitian}

1. Data spasial peta RTRW Kota Mataram, skala 1 : 25000

2. Data hasil survey lokasi pemakaman yang ada se Kota Mataram.

3. Peraturan Menteri Pekerjaan Umum Nomor 05/PRT/M/2008 tentang Pedoman Penyediaan Dan Pemanfaatan Ruang Terbuka Hijau Di Kawasan Perkotaan 
4. Peraturan Daerah Nomor 12 Tahun 2011, tentang Rencana Tata Ruang Wilayah ( RTRW) Kota Mataram.

5. Data statistik jumlah kelahiran dan kematian 5 tahun terakhir

Alat Penelitian

Peralatan yang digunakan dalam pengolahan data penelitian ini terdiri dari perangkat keras (hardware) dan perangkat lunak (software)

I. Perangkat keras (hardware)

Satu unit personal computer spesifikasi processor Pentium IV, Camera digital. GPS Garmin type GPSMAP 78S pengukuran koordinat makam.

II. Perangkat Lunak (Software)

1) Data Spasial Bing Aerial Imagery tahun 2013 dari Instansi terkait.

2) Program ArcGis 13 untuk mengolah data spasial dan SMCE.

3) Program Auto Cad r.8, untuk menggambar penataan fisik makam prioritas

4) MS Word dan Exel, untuk pembuatan laporan.

\section{PROSES PENELITIAN DAN ANALISIS DATA}

Proses Inventarisasi dan Spasial Sebaran Makam Di Kota Mataram.

Dari hasil survai makam diperoleh jumlah dan luas makam, jenis dan tingkat kepadatan masingmasing makam. Hasil survai juga mendapatkan rekapitulasi jumlah dan peluang pengembangan makam.

\section{Proses Perhitungan Estimasi Kebutuhan Makam Di Kota Mataram.}

Untuk mendapatkan perhitungan luasan kebutuhan pemakaman muslim dilakukan tiga model perhitungan yaitu berdasarkan:

\section{a. Peraturan Menteri Pekerjaan Umum Nomor 05/PRT/M/2008.}

Dengan pendekatan populasi penduduk, ketentuan pemakaman untuk perkotaan adalah luas minimal perkapita $1,2 \mathrm{~m}^{2}$ lokasi tersebar.

b. Formula Santarsiero (2000) dari Italia

Untuk mengetahui kebutuhan luasan makam pada periode tertentu dengan rumus sebagai berikut:

$$
C=\frac{P . m . t . u}{1000}+s t+b+S e+\text { Sre }
$$

Untuk menghitung kebutuhan area pemakaman dengan rumus ini menjadi sulit karena bangunan makam (b) tidak bisa disamaratakan/disetarakan antara satu dengan lainnya disebabkan bangunan makam sangat variatif tergantung model dan selera dari keluarga atau masyarakat pada waktu tertentu. Hal ini akan berpengaruh juga pada variable (st) jarak antar makam, sehingga perhitungan berdasarkan pendekatan jumlah angka kematian dan kelahiran periode tertentu dihitung dengan rumus sebagai berikut:
1. Menghitung angka kematian dalam periode waktu tertentu:

$$
P_{M}=\sum_{i=1}^{n}\left((1+R g)^{i-1} \cdot P_{t h i} \cdot R_{M}\right)
$$

2. Jumlah makam yang dibutuhkan berdasarkan jumlah angka kematian

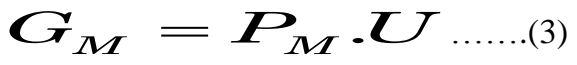

3. Luas area yang diperlukan untuk tempat pemakaman

$C_{M}=\mathrm{G}_{\mathrm{M}}+[$ Sre $]+[1+\mathrm{Se}]$

$P_{M}=$ Jumlah angka kematian dalam periode waktu tertentu

$C_{M}=$ luas area yang diperlukan untuk tempat pemakaman

$G_{M}=$ area yang diperlukan untuk makam

$\boldsymbol{U}=$ besaran makam, $2 \mathrm{~m}^{2} /$ jenazah

$\mathrm{Se}=$ Parameter untuk area cadangan $\left(10 \%\right.$ dari $\left.\mathrm{G}_{\mathrm{M}}\right)$

Sre = ruang yang diguankan untuk fasilitas saran prasarana ( $15 \%$ dari dari $\mathrm{G}_{\mathrm{M}}$ )

c. Kombinasi perhitungan kedua model a dan b di atas.

Dengan mengadopsi peraturan dalam Permen Pekerjaan Umum terhadap beberapa variabel yang bersifat variatif dalam rumus Santarsiero maka komponen variabel menjadi terakomodir. Variabel dimaksud adalah

1. Mengganti ukuran makam $3,5 \mathrm{~m}^{2} /$ jenazah (Santarsiero, 2000) menjadi $2 \mathrm{~m}^{2} /$ jenazah (Permen PU).

2. Jarak antar makam (st) $=1,75 \mathrm{~m}^{2}$ mengikuti Permen PU

3. Bangunan makam (b) mengikuti ukuran makam karena bangunan makam tidak dikenal dalam makam muslim.

Proses Analisis SMCE Pendukung Pengambilan Keputusan Pencarian Lokasi Pengembangan Makam dan Prioritas Penataan Makam di Kota Mataram.

Tahap perancangan Alur pikir SMCE penataan makam adalah memberi standarisasi bobot pada indikator masing-masing kriteria melalui proses hirarki analisis. Bobot dalam setiap komponen indikator diberi nilai dimana bobot terendah diberikan 1 (satu) dan tertinggi 4 (empat) yaitu kategori sangat sesuai, nilai 3 (tiga) sesuai, nilai 2 (dua) cukup sesuai dan kurang sesuai diberi nilai 1 (satu)..

Hasil dari analisis SMCE yang menjadi keluaran yaitu peta Klas Kesesuaian Makam Kota Mataram. Makam dengan katagori sangat sesuai diseleksi untuk mendapatkan area yang dapat dikembangkan yaitu sinkronisasi luasan lahan hasil 
SMCE dan GIS lokasi terpilih sesuai estimasi kebutuhan luasan tiap kecamatan di Kota Mataram. Selanjutnya melakukan seleksi usulan penataan makam dengan kriteria makam eksisting memiliki luas di atas 10 are, memiliki tingkat kepadatan dibawah 50\% dan merupakan makam muslim.

\section{HASIL DAN PEMBAHASAN}

Hasil Inventarisasi dan Implementasi Spasial Makam Kota Mataram

Hasil survey dan pengolahan data diperoleh data baru berupa jumlah dan luasan makam, jenis makam berdasarkan agama, status makam, tingkat kepadatan makam dan makam-makam yang masih bisa dikembangkan. Peta lokasi makam di kota Mataram dapat dilihat pada Gambar 2:

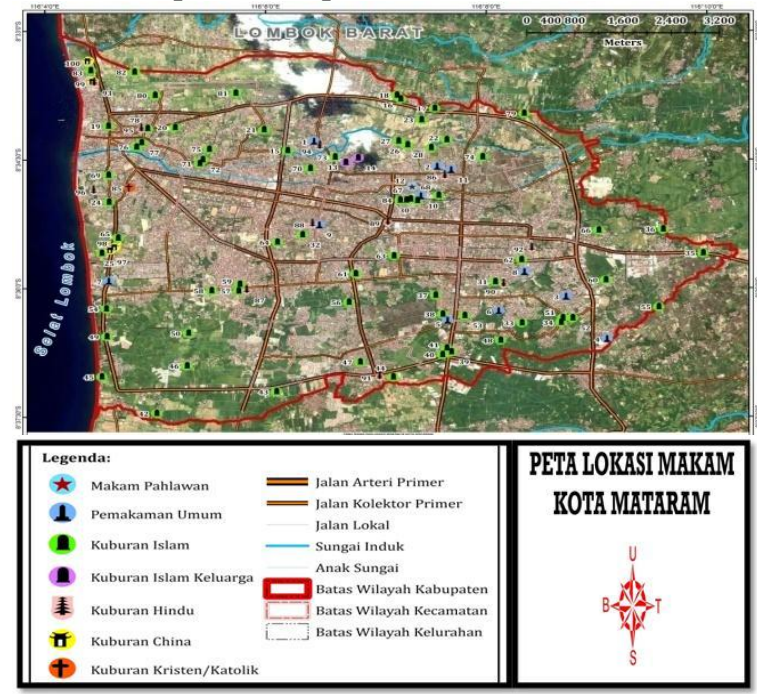

Gambar 2. Peta Lokasi Makam di Kota Mataram

Tabel 1. Jumlah dan Luas Makam di Kota Mataram

\begin{tabular}{|c|c|c|c|c|c|}
\hline \multirow[b]{2}{*}{ NO } & \multirow[b]{2}{*}{ KECAMATAN } & \multicolumn{4}{|c|}{ JUMLAHDAN LUAS MAKAM } \\
\hline & & $\begin{array}{l}\text { Jumlah } \\
\text { Makam } \\
\text { Muslim }\end{array}$ & $\begin{array}{c}\text { Luas } \\
\text { Makam } \\
\text { Muslim } \\
\left(\mathrm{m}^{2}\right)\end{array}$ & $\begin{array}{c}\text { Jumlah } \\
\text { Total } \\
\text { Makam }\end{array}$ & $\begin{array}{c}\text { Luasan } \\
\text { Total } \\
\text { makam } \\
\left(\mathrm{m}^{2}\right)\end{array}$ \\
\hline 1 & Mataram & 7 & 21.720 & 10 & 57,452 \\
\hline 2 & Selaparang & 17 & 38.592 & 19 & 47,665 \\
\hline 3 & Ampenan & 14 & 60.013 & 20 & 196,422 \\
\hline 4 & Sekarbela & 16 & 46.104 & 18 & 67,223 \\
\hline 5 & Cakranegara & 9 & 13.893 & 13 & 66,275 \\
\hline 6 & Sandubaya & 20 & 59.854 & 20 & 59,854 \\
\hline & ЛUМLАН & 83 & 240.175 & 100 & 494,890 \\
\hline
\end{tabular}

\section{Hasil Estimasi Kebutuhan Luasan Makam Kota Mataram}

\section{a. Berdasarkan Permen PU Nomor 05/PRTM/2008}

Berdasarkan Permen PU ini, kebutuhan luas makam di Kota Mataram dapat diestimasikan dan ditabelkan dalam Tabel 2 di bawah ini:

Tabel 2. Kebutuhan Luas Makam Kota Mataram

\begin{tabular}{|c|c|c|c|c|c|r|}
\hline $\begin{array}{c}\text { KOTA } \\
\text { MATARAM }\end{array}$ & $\begin{array}{c}\text { Proyeksi } \\
\text { Jumlah } \\
\text { Penduduk }\end{array}$ & $\begin{array}{c}88 \% \\
\text { Muslim }\end{array}$ & $\begin{array}{c}\text { Standar } \\
1,2 \mathrm{~m} 2 \text { /Tiwa }\end{array}$ & \multicolumn{2}{|c|}{$\begin{array}{c}\text { Makam Muslim } \\
\text { Yang Ada }\end{array}$} & $\begin{array}{c}\text { Kekurangan } \\
\text { Lahan }\end{array}$ \\
\hline & & & & Jumlah & Luasan & Luas (m2) \\
\hline 2015 & 432,724 & 380,797 & 456.956 & 83 & 240.175 & 216.781 \\
\hline 2020 & 467,316 & 411,238 & 493,485 & 83 & 240.175 & 253.310 \\
\hline 2025 & 504,673 & 444,112 & 532,935 & 83 & 240.175 & 292.760 \\
\hline 2030 & 545,016 & 479,614 & 575,537 & 83 & 240175 & 335.362 \\
\hline
\end{tabular}

\section{b. Kombinasi Permen PU dan Formula Santarsiero (2000)}

Rekapitulasi 3 model perhitungan estimasi Kebutuhan Makam di Kota Mataram Tahun 2030 sebagaimana disajikan dalam Tabel 3 sebagai berikut:

Tabel 3. Estimasi Kebutuhan Luas Makam Kota Mataram Tahun 2030

\begin{tabular}{|r|l|c|c|c|}
\hline No & \multicolumn{1}{|c|}{ Formula Estimasi } & $\begin{array}{c}\text { Permen PU } \\
\left(\mathrm{m}^{2}\right)\end{array}$ & $\begin{array}{c}\text { Santarsiero } \\
\left(\mathrm{m}^{2}\right)\end{array}$ & $\begin{array}{c}\text { Kombinasi } \\
\left(\mathrm{m}^{2}\right)\end{array}$ \\
\hline 1 & Luas satumakam (C) & 3,75 & variatif & 3,75 \\
\hline 2 & Jumlah angka kematian tahun 2030(PM) & - & 16.824 & 16.824 \\
\hline 3 & $\begin{array}{l}\text { Luas makam berdasarkan jumlah angka } \\
\text { kematian (GM) }\end{array}$ & $\begin{array}{c}335.361 \times 70 \\
\%\end{array}$ & 58.886 & 33.648 \\
\hline 4 & $\begin{array}{l}\text { Luas area yang diperlukan untuk makam } \\
\text { tahun 2030(CM) }\end{array}$ & 335.361 & $\mathbf{8 3 . 5 9 0}$ & $\mathbf{5 2 . 0 0 0}$ \\
\hline - KebutuhanLahan Makam Muslim Sampai Dengan Tahum 2030 & $\mathbf{5 7 5 . 5 3 7}$ \\
\hline - KebutuhanLahan Makam Non Muslim Sampai Dengan Tahum 2030 & 78.482 \\
\hline - Jumlah Makam Hasil Survey 2014 & $\mathbf{1 . 1 4 8 . 9 1 0}$ \\
\hline - Jumlah Total Kebutuhan Luasan Makam Muslim+Non Muslim di Kota \\
Mataram sampai Th 2030 (Permen PU)
\end{tabular}

Hasil Analisis Spasial Multi Kriteria Evaluasi (SMCE) dan Sistem Informasi Geografis (SIG) Pencarian Area Pengembangan Makam

Peta yang dihasilkan adalah peta Klas Kesesuaian Makam dari hasil ionisasi masingmasing poligon dalam peta kriteria Kebijakan, Ekonomi, Fisik/Teknis danSosial Budaya. ke dalam polygon peta Pola Ruang Kota Mataram. Penilaian kesesuaian kriteria dengan kategori sangat sesuai dapat dilihat pada Tabel 4.

Tabel 4. Penilaian Kesesuaian Kriteria Sangat

Sesuai

\begin{tabular}{|r|r|l|c|}
\hline No. & Indikator & \multicolumn{1}{|c|}{ Penjelasan } & Nilai \\
\hline 1. & $\begin{array}{c}\text { Kriteria } \\
\text { Penilaian }\end{array}$ & SANGAT SESUAI & $\mathbf{4}$ \\
\hline & a. & $\begin{array}{l}\text { Rencana Makam berada di tanah kososng, lapangan, } \\
\text { Padang rumput }\end{array}$ \\
\hline b. & $\begin{array}{l}\text { Rencana Makam berada di jalan kolektor Sekunder } \\
\text { dan sekitarnya, atau sekitar makam eksisting yg } \\
\text { masih bisa dikembangkan }\end{array}$ \\
\hline & c. & $\begin{array}{l}\text { Bebas Banjir,dengan curah hujan 0 sd. 1300 dengan } \\
\text { ketinggian 62.5 keatas }\end{array}$ \\
\hline
\end{tabular}


Selanjutnya hasil pembobotan dengan AHP disajikan pada Tabel 5 di bawah ini.

Tabel 5. Hasil Pembobotan dengan AHP

\begin{tabular}{|r|c|l|c|c|}
\hline \multicolumn{1}{|c|}{ No } & Kriteria & \multicolumn{1}{|c|}{ Sub Kriteria (Indikator) } & Bobot & Nilai \\
\hline $\mathbf{1}$ & Kebijakan & & $\mathbf{0 . 5 3}$ & \\
\hline & & Tanah Kosong & 0.34 & 4 \\
\hline & & Permukiman & 0.29 & 3 \\
\hline & & Pertanian & 0.23 & 2 \\
\hline & & Budidaya lainnya & 0.14 & 1 \\
\hline $\mathbf{2}$ & Ekonomi & & $\mathbf{0 . 1 1}$ & \\
\hline & & Potensi lahan Untuk Makam & 0.29 & 3 \\
\hline & & Jarak terhdp jalan & 0.23 & 2 \\
\hline & & Jarak Makam Terhadap Pemukiman & 0.35 & 4 \\
\hline & & Jarak Ke Lokasi potensial & 0.13 & 1 \\
\hline $\mathbf{3}$ & \multirow{2}{*}{ Fisik } & & 0.16 & \\
\hline & & & 0.27 & 3 \\
\hline & & Topografi & 0.16 & 1 \\
\hline & & Rarah Hujan Banjir & 0.23 & 2 \\
\hline & & Luas Area Makam & 0.34 & 4 \\
\hline & \multirow{2}{*}{ Sosial Budaya } & & 0.20 & \\
\hline & & Demografi & 0.29 & 3 \\
\hline & & Agama & 0.34 & 4 \\
\hline & & Adat Istiadat Tradisi & 0.24 & 2 \\
\hline & & Psichologis & 0.13 & 1 \\
\hline
\end{tabular}

Peta Klas Kesesuaian Makam adalah hasil ionisasi masing-masing poligon dalam peta kriteria Kebijakan, Ekonomi, Fisik dan Sosial Budaya ke dalam polygon peta Pola Ruang Kota Mataram dengan Kesesuaian pengembangan makam bernilai 4 (sangat sesuai) jika berada di kawasan RTH, permukiman bernilai 3 (sesuai), pertanian bernilai 2 (cukup sesuai) dan kawasn budidaya lainnya bernilai 1 (kurang sesuai) dengan hasil sebagaimana terlihat pada Gambar 3 berikut:

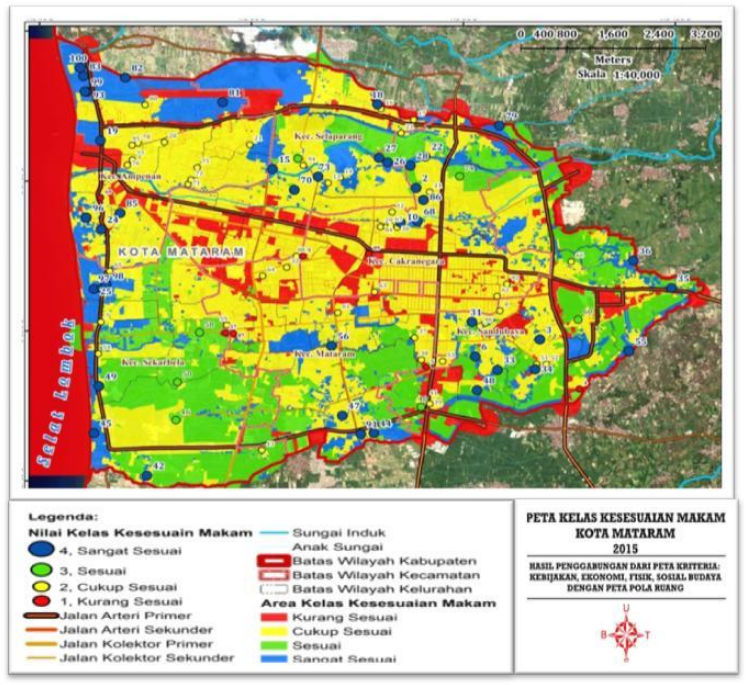

Gambar 3. Peta Kelas Kesesuaian Makam Kota Mataram

\section{Pengembangan Analisis Pendukung Keputusan Penentuan Prioritas Makam Kota Mataram}

Tahapan ini menghasilkan dua luaran, yaitu:

\section{a. Usulan Lokasi Pengembangan Makam Muslim Tiap Kecamatan}

Diperoleh makam-makam yang berkatagori sangat sesuai atau bernilai 4 (empat) sejumlah 42 makam, 18 makam yang memiliki area pengembangan dan terpilih 16 makam muslim saja.

\section{b. Penentuan Urutan Prioritas Penataan Fisik Makam.}

Dari 16 (enam belas) makam prioritas pengembangan makam Muslim Kota Mataram terseleksi makam terpilih sesuai kriteria dan AHP. yaitu makam Bagirati di Kecamatan Cakranegara dengan score $32 \%$.

Hasil analisis lokasi pengembangan dan penataan fisik makam di Kota Mataram selengkapnya dapat dilihat pada Tabel 6.

Tabel 6. Analisis Lokasi Pengembangan dan Penataan Fisik Makam Kota Mataram

\begin{tabular}{|c|c|c|c|c|c|c|}
\hline No & NAMAMAKAM & \begin{tabular}{|c|} 
Luas Makam \\
Eksisting
\end{tabular} & Kepadalen makam & \multicolumn{2}{|c|}{$\begin{array}{l}\text { EstimasiKebuluhnen Dan } \\
\text { Ketersedian GIS meklam }\end{array}$} & Pronilas Penalaan \\
\hline \multicolumn{5}{|c|}{ EstimasiKebuutunan Mekam di Kecamatan Ampenan } & \multicolumn{2}{|r|}{ Andisis } \\
\hline & Kebon Talo & $650 \mathrm{~m}^{2}$ & $25 \%<x<50 \%$ & $64.004,46 \mathrm{~m}^{2}$ & Terpenuhi & $\angle 10$ Are \\
\hline & Baloglbe & $3064 \mathrm{~m}^{2}$ & $5096<x<75 \%$ & $6.423,42 \mathrm{~m}^{2}$ & Kurang & $>50 \%$ \\
\hline & Mbiqumar & $2167 \mathrm{~m}^{2}$ & $5096<x<75 \%$ & $15.2181,75 \mathrm{~m}^{2}$ & Terpenuhi & $>50 \%$ \\
\hline & Tingyar & $1201 \mathrm{~m}^{2}$ & $50 \%<x<75 \%$ & $21.624,69 \mathrm{~m}^{2}$ & Kurang & $250 \%$ \\
\hline \multicolumn{7}{|c|}{ Estimasi Kebutuhan Makam di Kecamatan Sekarbela $=30.833 \mathrm{M}^{2}$} \\
\hline & TPUPerumnas & $2203 \mathrm{~m}^{2}$ & $5096<x<75 \%$ & $1.194,65 \mathrm{~m}^{2}$ & Kurang & $750 \%$ \\
\hline & Kekalik Ginsek & $2186 \mathrm{~m}^{2}$ & $25 \%<x 550 \%$ & $1.417,09 \mathrm{~m}^{2}$ & Kurang & Terpenuhi \\
\hline & BatuRinggit & $759 \mathrm{~m}^{2}$ & $25 \%<\times 50 \%$ & $4.030,31 \mathrm{~m}^{2}$ & Kurang & $\angle 10 \mathrm{Are}$ \\
\hline 8 & Mepak Indeh & $2160 \mathrm{~m}^{2}$ & $5096<x<75 \%$ & $44.081,82 \mathrm{~m}^{2}$ & Terpenuhi & $>50 \%$ \\
\hline & Sembalin & $276 \mathrm{~m}^{2}$ & $25 \%<\times<50 \%$ & $3.723,43 \mathrm{~m}^{2}$ & Kurang & Terpenuhi \\
\hline & Batu Meáni & $677 \mathrm{~m}^{2}$ & $25 \%<x<50 \%$ & $49.598,73 \mathrm{~m}^{2}$ & Temenuni & $\angle 10$ Are \\
\hline \multicolumn{4}{|c|}{ Estimasi Ketutuhan Makam Di Kecamatan Mataram } & $83.047 \mathrm{~m}^{2}$ & & \\
\hline 11 & Nurussalam & $606 \mathrm{~m}^{2}$ & $75 \%<<<80 \%$ & $91.647,01 \mathrm{~m}^{2}$ & Terpenuhi & $<10$ Are dan $>50 \%$ \\
\hline \multicolumn{7}{|c|}{ Estimasi Kebutuhan Nakam Di Kecamatan Selaparang $=64.685 \mathrm{~m}^{2}$} \\
\hline & Kamesen & $5998 \mathrm{~m}^{2}$ & $5096<x<75 \%$ & $2,113,03$ & Kurang & $>50 \%$ \\
\hline 13 & Monick & $3637 \mathrm{~m}^{2}$ & $50 \%<x<75 \%$ & $69.469,13$ & Terpenchi & $>50 \%$ \\
\hline & Dasesn Sari & $964.1 \mathrm{~m}^{2}$ & $50 \%<x<75 \%$ & 5728,13 & Kurang & $750 \%$ \\
\hline \multicolumn{7}{|c|}{ Esimas Ketutuhan Nakam Di Kecamatan Cakranegara $=46.921 \mathrm{~m}^{2}$} \\
\hline & BagiRati & $4005 \mathrm{~m}^{2}$ & $0 \%<x<5 \% \%$ & $65.927,31$ & Terpenuhi & Terpenuhi \\
\hline \multicolumn{7}{|c|}{ Estimasi Kebutuhan Mekam Di Kecamatan Sandubaya $=27.246 \mathrm{~m}^{2}$} \\
\hline & Babakn Barat & $6035 \mathrm{~m}^{2}$ & $25 \%<x<50 \%$ & $27.509,94$ & Terpenuhi & Terpenuhi \\
\hline \multirow{2}{*}{\multicolumn{3}{|c|}{ KOTAMATARAM TH. 2030}} & Kebutuhan & $335.362 \mathrm{~m}^{2}$ & & \\
\hline & & & Ketersediaan & $610.625,10 \mathrm{~m}^{2}$ & & \\
\hline
\end{tabular}




\section{KESIMPULAN}

Dari pembahasan di atas dapat diambil kesimpulkan sebagai berikut:

1. Dengan menggunakan teknologi sistem informasi geografis jumlah makam yang terinventarisasi di Kota Mataram sejumlah 100 makam dengan luasan total 494.890 $\mathrm{m}^{2}$, yang terdiri dari 83 makam muslim seluas $240.175 \mathrm{~m}^{2}, 1$ makam pahlawan seluas $9.375 \mathrm{~m}^{2}$ dan 16 makam adalah makam non muslim seluas $245.340 \mathrm{~m}^{2}$.

2. Estimasi kebutuhan lahan pemakaman sampai tahun 2030 seluas 114,89 hektar dengan kebutuhan lahan untuk pemakaman muslim masih perlu disiapkan seluas 33,53 hektar dan non muslim masih kurang 7,85 hektar.

3. Dari hasil olahan GIS dan SMCE diperoleh jumlah lokasi makam dengan katagori sangat sesuai adalah 42 lokasi dan hanya 18 lokasi yang memiliki area pengembangan atau ruang kosong antara makam eksisting dengan permukiman terdekat dengan luas area pengembangan se Kota Mataram adalah $610.625 \mathrm{~m}^{2}$ dan terseleksi menjadi 16 makam muslim umum.

4. Hasil Analitik Hirarki Proses menunjukkan makam yang perlu mendapat prioritas utama penanganan penataan fisik adalah makam Bagirati di Kecamatan Cakranegara dengan score $32 \%$.

\section{DAFTAR PUSTAKA}

Barus, B. dan Wiradisastra. 2000. Sistem Informasi Geografi: Sarana Manajemen Sumberdaya. Laboratorium Penginderaan Jauh dan Kartografi, Jurusan Tanah, Fakultas Pertanian, IPB.

CIFOR, 1999. Panduan untuk Menerapkan Analisis Multikriteria dalam Menilai Kriteria dan Indikotor. Journal Center for International Forestry Research, Bogor.

Dian, Z., 2004. Land for The Dead: Locating Urban Cemeteries. Case Study Guilin, China, Thesis, ITC-Netherlands.

Perda, 2011. Peraturan Daerah Kota Mataram No.12 Tahun 2011 tentang Rencana Tata Ruang Wilayah Kota Mataram, Mataram.

Permen PU, 2008. Peraturan Menteri Pekerjaan Umum No.05/PRT/M.2008 tentang Pedoman Penyediaan dan Pemanfaatan
Ruang Terbuka Hijau di Kawasan Perkotaan, Jakarta.

Riyadi, G. dan Subaryono, 2008. Sistem Pendukung Keputusan Berbasis Sistem Informasi Geografis untuk Pengelolaan Tempat Pemakaman di Perkotaan, Jurnal Media Teknik, Yogyakarta.

UU, 2007. Undang-Undang No. 26 tahun 2007 tentang Tata Ruang. 